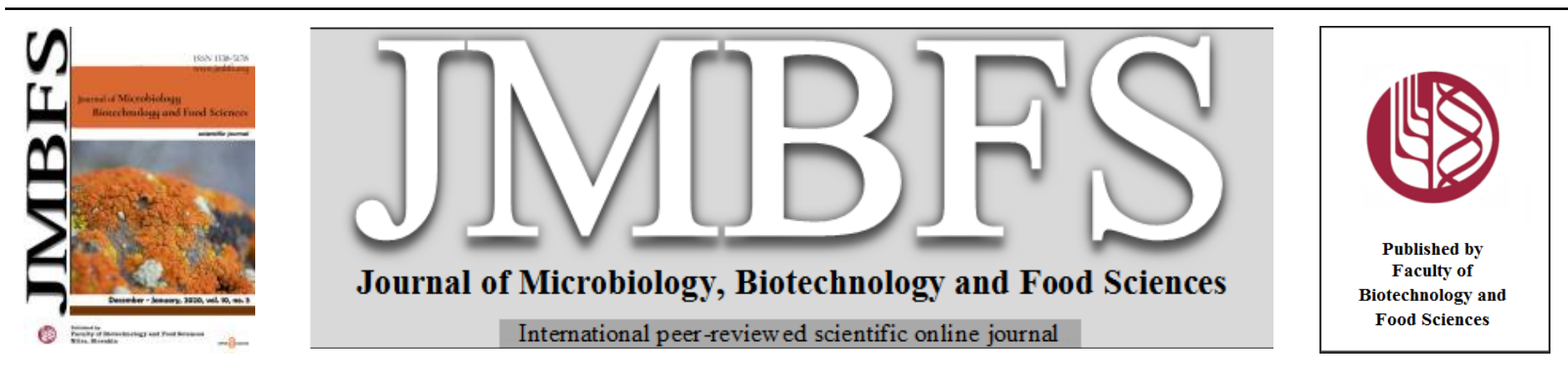

\title{
AMARANTH INFLUENCE ON WHEAT FLOUR DOUGH RHEOLOGY: OPTIMAL PARTICLE SIZE AND AMOUNT OF FLOUR REPLACEMENT
}

\author{
Ionica Coțovanu ${ }^{l}$, Georgeta Stoenescu ${ }^{2}$, Silvia Mironeasa $*^{1}$ \\ Address(es): Mironeasa Silvia, \\ ${ }^{1}$ Stefan cel Mare University of Suceava, Faculty of Food Engineering, University Street no.13, 720229, Suceava, Romania. \\ ${ }^{2}$ Arcada Research laboratory, Arcada Mill, Lunca Siretului, Zona Banda Barbosi 1 bis, 800416, Romania.
}

*Corresponding author: silviam@fia.usv.ro

doi: 10.15414/jmbfs.2020.10.3.366-373

\section{ARTICLE INFO}

Received 30. 4. 2020

Revised 8. 7. 2020

Accepted 13. 7. 2020

Published 1. 12. 2020

Regular article

OPEN OACCESS

\section{ABSTRACT}

Knowledge of various amaranth flour (AF) particle sizes influence added in different amounts in refined wheat flour (WF) seems necessary to properly design systems with expected rheological properties. The study aimed to assess the effects of factors, particle size and level of AF added in WF on Falling number index (FN) and dough rheological properties described by Mixolab in a systematic investigation based on design of experiment. The level of AF added in WF significantly influenced the FN values in the linear and quadratic terms $(\mathrm{p}<0.05)$, revealing a decrease with the level increase. Particle size played a significant role in increasing water absorption in linear and quadratic terms $(\mathrm{p}<0.05)$, whereas only the linear term has a significant effect $(\mathrm{p}<0.005)$ on dough development time and stability. Particle size increase and the interaction between particle size and AF significantly increased torques $\mathrm{C} 2$ and $\mathrm{C} 3$. AF level increase in WF significantly decreased the torques $\mathrm{C} 4$ and $\mathrm{C} 5$. The optimization results highlighted that the most suitable combination would be the composite flour with $9.74 \%$ AF of $280 \mu \mathrm{m}$ particle size incorporated in WF. The proposed approach and the information resulted can be relevant for industrial applications, helping to develop products with amaranth with optimum rheological properties, in order to scale-up the production.

Keywords: Rheology, Mixolab, Amaranth flour, Wheat flour, particle size

\section{INTRODUCTION}

Consumption of alternative crops such as Andean pseudo cereals is gaining popularity among people who adopt a healthy lifestyle. The opportunity to supplement refined wheat flour which has a low level of nutrients with higher nutritional value flour has attracted high interest for manufacturers involved in new bakery products development based on nutrient-dense ingredients. Amaranth flour is recognized as a functional ingredient due to its high-quality nutritional and technological properties, especially in baking processes, and due its multiple uses for processing and industrialization (Sanz-Penella et al., 2013). Besides the excellent nutritional value, amaranth grain present a potential agronomic importance across the world, being environmentally resistant crop which easily adapted to different conditions (Valcárcel-Yamani and Lannes, 2012; Rosell $\boldsymbol{e} t$ al., 2009). There are more than 60 species of amaranth ,but three species of genus Amaranthus originating in South America are the most important, A. hypochondriacus L. (México), A. cruentus L. (Guatemala) and A. caudatus L. (Peru and other Andean countries) being cultivated for grain production (Cárdenas-Hernández et al., 2016; Kaur et al., 2010). Because amaranth does not include gluten, makes it to be a nutritious food ingredient which contain high level of protein and carbohydrate that require the needs of the people with celiac disease, the individuals allergic to wheat, and the vegetarian persons. Healthpromoting attributes of amaranth seeds reside in hypocholesterolemic activity, improves the immune system, antitumor effect, decreases blood glucose levels, action acts on liver functions, hypertension, antienemiceffect, antioxidantactivity, celiac disease and antiallergic action (Caselato-Sousa and Amaya-Farfán, 2012).

In addition to being source of carbohydrate and a high quality protein with a well balanced amino acid composition, the amaranth seed provides dietary fiber, lipids rich in unsaturated fatty acids, adequate levels of minerals (zinc, copper, and manganese), vitamins (thiamine, niacin, riboflavin, and folate) and significant amounts of other bioactive components such as squalene, tocopherols, phenolic compounds (Chauhan et al., 2015; Inglett et al., 2015; Venskutonis and Kraujalis, 2013) that have known effects on human health (Kalinova and Dadakova, 2009). The researchers have found varying values of grain amaranth protein composition, from 13.10 to $21.00 \%$, depending on variety and environmental conditions (Akin-Idowu et al., 2017; Venskutonis and Kraujalis, 2013). Amaranth protein presents a high content of essential amino acids, especially lysine and methionine (Caselato-Sousa and Amaya-Farfán, 2012) and thus, it is superior to that of common cereals. The cysteine includes sulphur which improved gluten network by inter in sulphur bond.Hence, the addition of amaranth flour to wheat flour improves dough characteristics in wheat flour (Palombini et al., 2013). Comparatively with cereal starch, the amaranth starch is found in lower amounts and is located in the perisperm, not in the endosperm (Inglett et al., 2015; Valcárcel-Yamani and Lannes, 2012). Amaranth starch presents much lower amylose content than other cereal starches, whereas amylopectin content is high (Venskutonis and Kraujalis, 2013; Schoenlechner et al., 2008). Rapidly digestible starch was reported to be about $30 \%$ d.w. which leads to a lower predicted glycaemic index (87.2) compared to wheat starch (Kaur et al., 2010). The total fiber content of amaranth seeds varies between 11.14 and $20.6 \%$, wich depend on the species and conditions of growing (Venskutonis and Kraujalis, 2013; Valcárcel-Yamani and Lannes, 2012); the soluble fiber being in high quantity $(4.2 \%)$ (Caselato-Sousa and AmayaFarfán, 2012). Other researchers found that the grain amaranth contains 3 times the amount of fibre in wheat (Dhellot et al., 2006). The lipid content of amaranth is higher than cereal grains, ranging from 5.7 to $16.7 \%$ (Kraujalis and Venskutonis, 2013; Alvarez-Jubete et al., 2009). Theatty acids founds in high concentration in amaranth oils were palmitic (19\%), oleic $(26 \%)$ and linoleic (47\%) (Caselato-Sousa and Amaya-Farfán, 2012). The amaranth fats are found to be generally stable against oxidation, due to the presence of high amount of vitamin E. Valcárcel-Yamani and Lannes (2012) reported that amaranth contains bioactive compunds: riboflavin (0.19-0.23\%) and ascorbic acid (4.5\%). Some Amaranthus species contains other minor components such as phytosterols, waxes and terpene alcohols, which primarily depend on plant species and cultivar method. In respect to the minerals, calcium, magnesium, iron and zinc can be found in high amounts in comparison with wheat, the content being influenced by environmental conditions (Valcárcel-Yamani and Lannes, 2012; AlvarezJubete $\boldsymbol{e}$ t al., 2009). Other bioactive compounds (total phenolic acids) were found in amaranth seeds (Repo-Carrasco-Valencia et al., 2010), being a source of antioxidant valuable phenolic compounds (de la Rosa et al., 2009). 
Some research has shown an improved nutritional quality of bakery products when wheat flour is supplemented with amaranth, depending on the percentage added. There were studies revealing that amaranth substitution of 10-20\% improve some rheological properties of the dough without damaging quality. Amaranth flour was investigated as a replacement ingredient of wheat flour in various baked products such as bread, cakes, biscuits, pasta (Sanz-Penella et al., 2013; Capriles et al., 2008; Vitali et al., 2008; Sudha and Leelavathi, 2012). Most of the studies reported that amaranth has negative effect on loaf volume: this is due mainly to an excess amount addition which reduces gluten content of composite flour, and also leads to disruption of the starch-gluten matrix, thereby negatively influencing dough rheological properties. The negative effects can be diminished by using an adequate proportion of amaranth in wheat flour.

Particle reduction represents an important operation in food processing which is widely applied in the grain milling industry to separate the endosperm from the undesirable components of the whole grain (Ahmed et al., 2019). Several studies revealed that separation of the flour in different fractions vary in physical and chemical properties and thus provided possibility of production of specialty flours for different use products (Sakhare et al., 2013). The remarkable effects of particle size on rheological properties of various flour dough with different particle size was reported in some previously investigations (Ahmed et al., 2019; Iuga et al., 2019; Mironeasa et al., 2019; Ahmed et al., 2016; Ahmed et al., 2015; Moreira et al., 2014), highlighting that particle size and composition of the particle fractions influenced significantly the rheological properties in various ways. Some quality attributes of bread, such as volume and hardness are strongly influenced by the particle size of flours added; a higher particle sizes leads to lower hardness and higher volume (Martínez et al., 2014). Large particle size can have a negative impact on the bread quality due to the lower hydration and its integration in the gluten viscoelastic structure (Mironeasa et al., 2018; SanzPenella et al., 2013). On the other hand, the lower particle sizes showed a higher water holding capacity due to the surface area rising. The important role of wate content in the final product quality as a plasticizer that significantly affect rheological behavior has been reported (Amjid et al., 2013; Bhattacharya et al., 2006). The incorporation of large particle size rich in fiber and high levels of amaranth flour can have a detrimental effect on dough rheological and viscoelastic properties, and on bread functional properties, as well as on it organoleptic ones. Previous research have been trying to determine an optima amount of amaranth flour which could be used for substitution of wheat flour, but no work has been done to examine effects of particle size of amaranth flour. To our knowledge, no studies have been made yet to investigate into the main effect of particle size and amaranth seed flour level and interaction effect between particle size and level of amaranth flour added in wheat flour, on $\alpha$-amylase activity using Falling number tests and on dough characteristics using Mixolab.

The rheological equipment of a newer generation Mixolab, launched in 2004, has gained more and more popularity in assessing dough behaviour during mixing and also during the heating-cooling stage, simulating the behaviour of the dough inthe bread making process in only one single test. Mixolab can be used to feature the rheological behaviour of dough subjected to a dual mixing and temperature constraints (Moreira et al., 2012), allowing an extremely complex assessment of the changes. The Mixolab has been applied to evaluate the impact of particle size on quality attributes of reconstituted whole wheat flour (Wang $\boldsymbol{e}$ al., 2016; Liu et al., 2016) as well as the influence of milling whole wheat grains of different particle size on the thermo-mechanical properties (Bressiani et al., 2019).

Response surface methodology (RSM) RSM is a useful statistical tools which can be employed in order to diminish the number of samples necessary to evaluate the factors that affect the process and their interaction implying mathematica models and needing small time resources (Mironeasa and Mironeasa, 2019). Multiple-response process optimization technique has been successfully applied, in conjunction with desirability function for optimization of different composite flour formulation (Mironeasa et al., 2019a; Iuga and Mironeasa, 2019; Marcin et al., 2016)

Therefore, the aim of this study was to assess the effects of different amaranth flour particle size additions at different levels in refined wheat flour on dough rheological properties and to determine the optimal formulation of amaranth particle size-level added which will give the adequate dough rheological properties.

\section{MATERIAL AND METHODS}

\section{Basic materials}

Commercial refined wheat flour (WF) of 650 type used in this study was acquiered from the local market from Romania (MOPAN,Suceava) and consisted of $14.00 \%$ moisture (ICC 110/1), $12.60 \%$ protein (ICC 105/2), $1.40 \%$ fat (ICC 136), $0.65 \%$ ash (ICC 104/1), 30.00\% wet gluten (ICC 106/1), $6.00 \mathrm{~mm}$ gluten deformation index (SR 90:2007), and 312 s falling number index (ICC 107/1), being a good flour for bread making according to the Romanian standard SR 877:1996. The amaranth grains, acquired from S.C. SOLARIS PLANT S.R.L. (Ilfov, Romania), presented the following analytical characteristics: moisture content 14\% (SR EN ISO 665:2003), fat content 8.00\% (SR EN ISO 659:2009), protein content $17.00 \%$ (SR EN ISO 20483:2007), and ash content 3.00\% (SR ISO 2171:2009). The amaranth seeds were grounded in a laboratory grinder (Grain Mill, KitchenAid, Model 5KGM, Italy) and sieved through a Retsch Vibratory Sieve Shaker AS 200 basic (Haan, Germany) to obtain amaranth flour (AF) at three different particle size: large, $\mathrm{L}>300 \mu \mathrm{m}$, medium, $180 \mu \mathrm{m}>\mathrm{M}<$ $300 \mu \mathrm{m}$ and small fractions, $\mathrm{S}<180 \mu \mathrm{m}$.

\section{Experimental design and statistics}

The effects of two factors, particle size (PS) at 3 levels (L, M, S) and addition level of AF in wheat flour at five levels $(0,5,10,15$ and 20\%) on the falling number (FN) index, water absorption of amaranth-wheat flour dough and rheological properties using the Mixolab device as responses were investigated using response surface methodology (RSM) by means of general factorial design. The experimental design with real and coded factors values which led to 15 experimental formulations (Table 1) was built to allow the estimation of the main and interaction effects of the factors.

Table 1 Real and coded values of formulations factors

\begin{tabular}{lcccc}
\hline \multirow{2}{*}{ Run } & \multicolumn{2}{c}{ Coded values } & \multicolumn{2}{c}{ Real values } \\
\cline { 2 - 5 } & $\mathbf{X}_{\mathbf{1}}$ & $\mathbf{X}_{\mathbf{2}}$ & Particle size $(\boldsymbol{\mu m})$ & $\mathbf{A F}(\boldsymbol{\%})$ \\
\hline 1 & -1.000 & -1.000 & 180 & 0 \\
2 & -1.000 & 0.500 & 180 & 15 \\
3 & 1.000 & 0.500 & 380 & 15 \\
4 & 1.000 & 0.000 & 380 & 10 \\
5 & -1.000 & -0.500 & 180 & 5 \\
6 & -0.333 & -0.500 & 280 & 5 \\
7 & -0.333 & 0.000 & 280 & 10 \\
8 & 1.000 & 1.000 & 380 & 0 \\
9 & -1.000 & 0.000 & 180 & 10 \\
10 & -1.000 & 1.000 & 180 & 20 \\
11 & -0.333 & 1.000 & 280 & 20 \\
12 & -0.333 & 0.500 & 280 & 15 \\
13 & 1.000 & 1.000 & 380 & 20 \\
14 & -0.333 & -1.000 & 280 & 0 \\
15 & 1.000 & -0.500 & 380 & 5 \\
\hline
\end{tabular}

To describe the effects of two factors, particle size and amount of AF added in refined wheat flour on the fifteen responses, a polynomial quadratic regression equation (Eq.1) was applied where $Y$ is the response variable, $b_{o}, b_{1}, b_{2}, b_{11}, b_{22}$ and $b_{12}$ represent the regression coefficients for intercept, linear, quadratic and interaction effects respectively of $X_{1}$ and $X_{2}$ independent variables or factors (particle size of amaranth flour and level added in wheat flour) (Iuga and Mironeasa, 2019).

$$
Y=b_{o}+b_{1} \cdot X_{1}+b_{2} \cdot X_{2}+b_{11} \cdot X_{1}^{2}+b_{22} \cdot X_{2}^{2}+b_{12} \cdot X_{1} \cdot X_{2}
$$

The multiple linear regression analysis was applied to fit the data obtained for each response to linear, two factor interactions, quadratic and cubic models and the most adequately predictive model was selected by means of sequential $F$-test, coefficients of determination $\left(R^{2}\right)$, adjusted coefficients of determination ( $A d j$. $R^{2}$ ), and significant probabilities. In order to determine the validity of the model for each response, the experimental and predictive values were compared by paired $t$ test $(\mathrm{p}<0.05)$. Analysis of variance (ANOVA) was performed to evaluate the statistical significance of the coefficients in each predictive model. The polynomial response surfaces were generated showing the combined effect of the factors, particle size and addition level. Stat Ease Design-Expert 7.1 software (trial version) was employed to carry out the experimental design, the model analysis, generation of the response surface plots, test of model adequacy and the optimum level of formulation factors finding (Mironeasa et al., 2019a) The multiple responses analysis was applied to the predictive models fitted in order to find the optimal value of the factors, amaranth flour particle size and addition level. In the optimization process, each predicted response is transformed into an individual desirability function, $d_{n}$ which comprise the desired and researcher's priorities when building the optimization procedure for each of the factors. The individual desirability functions are then combined into a single composite response, named overall desirability function, $D$ (Eq. 2) computed as the geometric mean of the individual desirability $d_{n}$ which varies from 0 to 1 (Wu et al., 2011).

$$
D=\left(d_{1} \times d_{2} \times \ldots \times d_{n}\right)^{(1 / n)}
$$

where $d_{l}, d_{2}, \ldots d_{n}$ represent the individual desirability function and $n$ is the number of responses.

For the numerical optimization, dough stability (ST) and starch gelatinization, as the differences between $\mathrm{C} 3$ and $\mathrm{C} 2(\mathrm{C} 3-2)$ were set as maximum, while protein weakening, as the differences between $\mathrm{C} 1$ and $\mathrm{C} 2$ (C1-2) and starch 
recrystallization during paste cooling, as the differences between $\mathrm{C} 5$ and $\mathrm{C} 4$ (C5 4) were set as minimum. The level of all remaining responses which considered in this study was kept within range.

\section{Falling Number Evaluation}

The Falling number (FN) method, based on viscosity, was applied in order to achieve a proximate estimation evaluation of the $\alpha$-amylase activity in the composite flour formulated. The FN values were determined according to ICC standard method 107/1.

\section{Evaluation of rheological characteristics by Mixolab}

Mixing and starch pasting characteristics of samples formulation according to the experimental design (Table 1) were studied using the Mixolab equipment (Chopin, Tripette et Renaud, Paris, France) with standard option "Copin+" protocol. The composite flour rheological characteristics were determined according to ICC standard method no. 173 (ICC, 2010). The protocol used for determining the rheological behaviour of amaranth-wheat flour was: dough mixing at constant mixing rate of $80 \mathrm{rpm}$ and temperature of $30^{\circ} \mathrm{C}$ during $8 \mathrm{~min}$, heating rate $4^{\circ} \mathrm{C} / \mathrm{min}$ up to $90^{\circ} \mathrm{C}$, cooling rate of $4^{\circ} \mathrm{C} / \mathrm{min}$ up to $50^{\circ} \mathrm{C}$, and total time to run the analysis of $45 \mathrm{~min}$. All the samples were made at the optimum hydration level of the composite flour formulated that lets to achieve the optimum consistency of dough corresponding to the $\mathrm{C} 1$ torque value of $1.1 \mathrm{~N} \cdot \mathrm{m}$. Several preliminary mixing tests were made in order to determine the optimum hydration level to reach the maximum consistency of dough $(\mathrm{C} 1=1.1 \mathrm{~N} \cdot \mathrm{m})$ and then complete test has been applied to determine the dough properties as function of mixing and temperature. The following mixing parameters from the registered Mixolab curves were determined: water absorption, WA (\%) or percentage of water needed to achieve the maximum consistency torque $\mathrm{C} 1$ of $1.1 \mathrm{~N} \cdot \mathrm{m}$, dough development time, DDT (min) - the time to reach the maximum torque at $30^{\circ} \mathrm{C}$ and stability, ST (min) as time in min until the loss of consistency does not exceeds $11 \%$ of the $\mathrm{C} 1$ torque. When dough temperature increases, due to the protein reduction the minimum consistency, $\mathrm{C} 2(\mathrm{~N} \cdot \mathrm{m})$ torque was recorded. Then, when dough temperature increases to certain values, the starch gelatinization was given through the values of maximum consistency, C3 torque $(\mathrm{N} \cdot \mathrm{m})$, the stability of starch gel by minimum consistency, $\mathrm{C} 4$ torque $(\mathrm{N} \cdot \mathrm{m})$ and starch retrogradation when cooling dough through maximum consistency, C5 torque $(\mathrm{N} \cdot \mathrm{m})$. In addition, the difference between the $\mathrm{C} 1$ and $\mathrm{C} 2$ torques $(\mathrm{N} \cdot \mathrm{m})$ which is a measure of the protein weakening, the difference between the $\mathrm{C} 2$ and
C3 torques $(\mathrm{N} \cdot \mathrm{m})$ which measures the starch gelatinization, the difference between the $\mathrm{C} 3$ and $\mathrm{C} 4$ torques $(\mathrm{N} \cdot \mathrm{m})$ which is related to starch breakdown and the difference between the $\mathrm{C} 5$ and $\mathrm{C} 4$ torques $(\mathrm{N} \cdot \mathrm{m})$ related to retrogradation of starch during paste cooling were recorded.

\section{RESULTS AND DISCUSSION}

The results obtained are presented in Table 2 and shows the effects of formulation factors, particle size and addition level on FN value of amaranthwheat composite flour and Mixolab rheological parameters presented as their corresponding regression coefficients in the quadratic model. The accuracy test of the model (Table 2) showed that the quadratic model predict properly the studied parameters as a function of the formulation factor.

The falling number (FN) index values of amaranth-wheat composite flours formulated ranged from 289 to $321 \mathrm{~s}$. As shown in Table 2, the level of amaranth flour (AF) added, has a significant negative effect on the FN, while the particle size has a non-significant effect $(p>0.05)$. FN was significantly correlated $(p<0.05)$ with the interaction effect of AF addition level in WF and particle size and, also with quadratic effect of AF addition level. By ANOVA, the correlation coefficient value $\left(R^{2}\right)$ of this model was determined to be 0.70 , while the adjusted determination coefficient value $\left(A d j .-R^{2}\right)$ was 0.55 , showing that the regression model defined well the real $\alpha$-amylase activity of the composite flour through FN index. The negative coefficient of the AF addition level indicated that the FN index of amaranth-wheat composite flour decreased with increasing levels. The effects of particle sizes and AF addition level is shown in Figure 1a indicating a decrease of FN index with AF addition increase. This trend suggests an increase of the $\alpha$-amylase activity in the composite flour when the AF addition level in WF increases, knowing that the FN index is inversely correlated with $\alpha$ amylase activity in flour (Struyf $\boldsymbol{e t}$ al., 2016). The increase of $\alpha$-amylase activity of the mixture is related to the metalloenzyme character of $\alpha$-amylase whose activity depends on the presence of calcium ions in its structure (Suandarram $\boldsymbol{e t}$ al., 2014). It is known that amaranth seed contain a high level of calcium (SanzPenella et al., 2013; Alvarez-Jubete et al., 2009) and therefore an increased level of amaranth flour in the amaranth-wheat composite flour will result in an increase of $\alpha$-amylase activity mixture, improving final product quality.

Table 2 Regression coefficients in the predictive models represented as a function of variations in the formulation factors for FN value and wheat flour dough Mixolab characteristics

\begin{tabular}{|c|c|c|c|c|c|c|c|c|c|c|c|c|}
\hline \multirow[b]{2}{*}{ Factors $^{b}$} & \multicolumn{12}{|c|}{ Parameters } \\
\hline & $\begin{array}{r}\text { FN } \\
\text { (s) }\end{array}$ & $\begin{array}{l}\text { WA } \\
(\%)\end{array}$ & $\begin{array}{c}\text { DT } \\
(\mathbf{m i n})\end{array}$ & $\begin{array}{c}\text { ST } \\
(\mathbf{m i n})\end{array}$ & $\begin{array}{c}\mathbf{C 2} \\
(\mathbf{N} \cdot \mathbf{m})\end{array}$ & $\begin{array}{c}\text { C1-2 } \\
(\mathbf{N} \cdot \mathbf{m})\end{array}$ & $\begin{array}{c}\text { C3 } \\
(\mathbf{N} \cdot \mathbf{m})\end{array}$ & $\begin{array}{c}\mathrm{C3-2} \\
(\mathrm{N} \cdot \mathrm{m})\end{array}$ & $\begin{array}{c}\text { C4 } \\
(\mathrm{N} \cdot \mathrm{m})\end{array}$ & $\begin{array}{c}\text { C3-4 } \\
(\mathrm{N} \cdot \mathrm{m})\end{array}$ & $\begin{array}{c}\mathbf{C 5} \\
(\mathbf{N} \cdot \mathbf{m})\end{array}$ & $\begin{array}{c}\text { C5-4 } \\
(\mathrm{N} \cdot \mathrm{m})\end{array}$ \\
\hline Constant & 316.25 & 58.450 & 2.890 & 9.950 & 0.520 & 0.600 & 1.760 & 1.250 & 1.580 & 0.180 & 2.380 & 0.800 \\
\hline$A$ & ns & $-0.780^{* * * *}$ & ns & $0.840^{* * *}$ & $0.045^{* * *}$ & $-0.050^{* * *}$ & $0.099^{* * *}$ & $0.054^{* * *}$ & ns & $0.073^{* * *}$ & ns & ns \\
\hline$B$ & $-4.730^{* *}$ & $0.170^{*}$ & $1.670^{* * * *}$ & $-0.830^{* *}$ & $-0.036^{* * *}$ & $0.029^{* * *}$ & $-0.180^{* * *}$ & $-0.150^{* * *}$ & $-0.330^{* * *}$ & $0.015^{\text {*** }}$ & $-0.620^{* * *}$ & $-0.260^{* * * *}$ \\
\hline$A \times B$ & $-5.850^{* *}$ & $-0.770^{* * * *}$ & ns & $0.780^{* *}$ & $0.042^{* * *}$ & $-0.044^{* * *}$ & $0.081^{* * *}$ & $0.040^{* *}$ & ns & $0.077^{* * *}$ & ns & ns \\
\hline$A^{2}$ & ns & $-0.420^{* *}$ & ns & ns & $-0.035^{* * *}$ & ns & ns & ns & ns & ns & ns & ns \\
\hline$B^{2}$ & $-7.900^{* *}$ & $0.580^{* *}$ & ns & ns & ns & $0.032^{* *}$ & ns & ns & ns & ns & ns & ns \\
\hline$R^{2}$ & 0.70 & 0.93 & 0.72 & 0.83 & 0.91 & 0.93 & 0.95 & 0.95 & 0.95 & 0.96 & 0.93 & 0.88 \\
\hline Adj. $-R^{2}$ & 0.55 & 0.89 & 0.57 & 0.73 & 0.87 & 0.89 & 0.93 & 0.92 & 0.92 & 0.94 & 0.89 & 0.82 \\
\hline$p$-value & 0.0205 & $<0.0001$ & $<0.0202$ & 0.0028 & $<0.0001$ & $<0.0001$ & $<0.0001$ & $<0.0001$ & $<0.0001$ & $<0.0001$ & $<0.0001$ & 0.0005 \\
\hline
\end{tabular}

water absorption, DT - development time, ST - stability, C2 - minimum consistency during protein weakening stage,

C1-2 - difference between torques $\mathrm{C} 1$ and $\mathrm{C} 2, \mathrm{C} 3$ - maximum consistency during starch gelatinization stage, C3-2 - difference between torques $\mathrm{C} 3$ and $\mathrm{C} 2$,

$\mathrm{C} 4$ - minimum consistency corresponding to hot starch stability gel, C3-4 - difference between torques $\mathrm{C} 3$ and $\mathrm{C} 4$, C5 - maximum consistency during starch retrogradation stage, $\mathrm{C} 5-4$ -

difference between torques $\mathrm{C} 5$ and $\mathrm{C} 4$

The addition of amaranth flour may improve the quality of the final baked products prepared especially from flour with a low $\alpha$-amylase activity as it is known that $\alpha$-amylase provides fermentable sugars leading to increased bread volume, improves crumb structure, intensifies crust colour (Mironeasa and Codină, 2017; Struyf et al., 2016).

Effects of the amaranth flour particle size and the levels added in refined wheat flour on the Mixolab rheological parameters

Amaranth flour addition of different particle sizes at various levels in refined wheat flour has deeply changed the rheological behaviour of dough measured with Mixolab, device which provides information on the protein quality and strength, amylolytic activity and starch gelling (Codină and Mironeasa, 2013) Parameters registered in five different stages of the Mixolab curve describe dough rheological properties during mixing, measures the speed of weakening of protein due to mechanical work and heat, starch gelatinization, the stability of hot-formed starch paste and starch retrogradation during the cooling stage.
Effects of formulation samples on dough rheological properties during mixing stage

During initial Mixolab kneading stage, the formation of a three-dimensional viscoelastic structure with gas-retaining properties is related to the distribution of the material, the disruption of the initially spherical protein particles and the hydration of the flour compounds that occur together with the stretching and alignment of the proteins (Rosell et al., 2007; Angioloni and Collar, 2009) When refined wheat flour was replaced by AF, dough consistency and stability that are mainly related to the aggregates formation as a result of hydrogen bonding or proteins linking through disulfide or dityrosine bonds, undergo modifies. AF addition in WF changes dough consistency at a given amount of added water depending on AF particle size and level. It is well-known that water absorption capacity influences the baking process, being also a significan economic indicator that affects the volume yield of the finite product. Water absorption (WA) of formulated samples varies from 56.70 to $60.50 \%$. The effect of particle size and AF addition level on WA of amaranth-wheat composite flour dough as their corresponding regression coefficients in the quadratic model 
indicates is shown in Table 2. The model showed that the linear and quadratic terms of particle size has a significant negative influence on the WA suggesting that with particle size decrease WA increases due to the greater surface area of the particles which absorbed more water These results are in agreement with the observation reported in the literature by Ahmed et al. (2019), Drakos et al (2017) for quinoa, rye and barley flours. The linear term of the AF addition level in WF has a non-significant effect $(p>0.05)$, but the quadratic term showed a significant effect $(p<0.05)$ on WA. Also, WA was significantly correlated with the interaction effect of particle size and $\mathrm{AF}$ addition level and, also with quadratic effect of particle size (Table 2). The test for the precision of the mode indicates that the quadratic model can be suitable to predict WA as a function of the formulation factors. The $R^{2}$ and $A d j .-R^{2}$ values showed that the regression model fitted to the experimental data of WA parameters showed higher $R^{2}$ value (0.93). The effect of particle size and AF level added in WF on the WA of amaranth-wheat composite flour dough is shown in Figure 1b. The response surface plot indicates that with the interaction effect between particle size and AF level increase, the WA decreased, result which can be expected. This decrease may be explained by the gluten dilution which requires less hydration and therefore a lower amount of water needed (Mohammed et al., 2014). On the other hand, an increase of WA with particle size decrease was found and can be related to the specific surface area of amaranth starch which is larger than wheat starches and small particle absorb more water compared to large and medium particle fractions. Similar result was reported by Iuga et al. (2019), Mironeasa $\boldsymbol{e t}$ al. (2019), Ahmed et al. (2016) whereby small particle size of non-gluten flour increases the values of WA.

Amaranth flour (AF) addition influenced the gluten network and changed dough development time (DT). The particle size did not significantly $(p>0.05)$ influence DT, while AF level added in WF has a significant effect $(p<0.05)$ on DT of amaranth-wheat composite flour which ranged from 1.33 to $5.75 \mathrm{~min}$. As shown in Table 2, the quadratic model was found to represent adequately the results for DT, as a function of the formulation factors, the $R^{2}$ and $A d j .-R^{2}$ values confirming the adequacy of the model. Figure $1 \mathrm{c}$ represents a response surface plot showing the effect of particle size and AF level added in WF on DT, revealing that DT increased abruptly (about 2 - 3 times) as the AF level increased above $10 \%$ comparatively to the control, depending on particle size. DT increases considerably in the composite flour with large particle size, showing that a long time is needed between the addition of water and the time when the dough reached the optimal elastic and viscous characteristics. The increase in DT can be explained by the addition of non-gluten flour which affects gluten quality. The DT value is a measure of dough strength and the higher it is the stronger is the dough.

Dough stability (ST) was affected $(p=0.02)$ by the particle size and AF addition level in WF. Regression model for ST (Table 2) showed a significant effect in linear term of particle size, AF addition level, and of the interaction terms between particle size and AF addition level, while the quadratic terms of factors formulation were non-significant $(p>0.05)$. Particle size affects positively ST, while AF addition level negatively influences it. The significant negative effect on dough stability given by the AF addition level may be probably due to gluten dilution because wheat flour was replaced with non-gluten flour and can reflect an increased degree of softening. On the other hand, an increase of dough stability with particle size increase, indicates an increase in the gluten network which denotes the fact that the composite dough with large particle size is able to sustain for a longer time the mechanical treatment during the bread making process. This increase can be related to some components from the particle size fractions because it was shown that amaranth albumins are able to interact with gluten proteins through disulfide bonds (Oszvald et al., 2009), increasing dough ST. The results of ANOVA show that the equations can be suitable to predict dough ST as a function of the particle size and AF level incorporated in WF. The $R^{2}$ and $A d j .-R^{2}$ values were adequate to confirm the significance of the model. A response surface plot for the stability (Figure 1d) showed that dough ST significantly decreased with an increase of AF level.

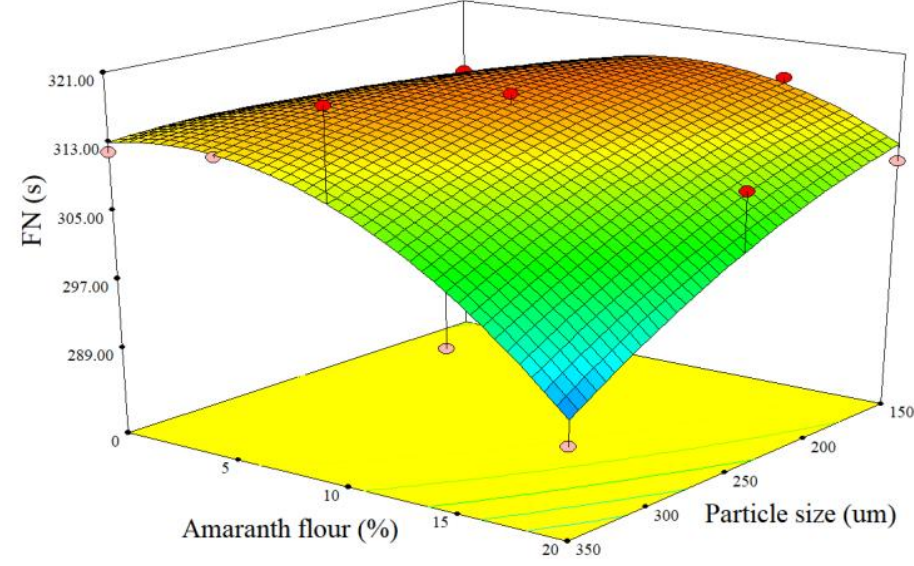

(a)

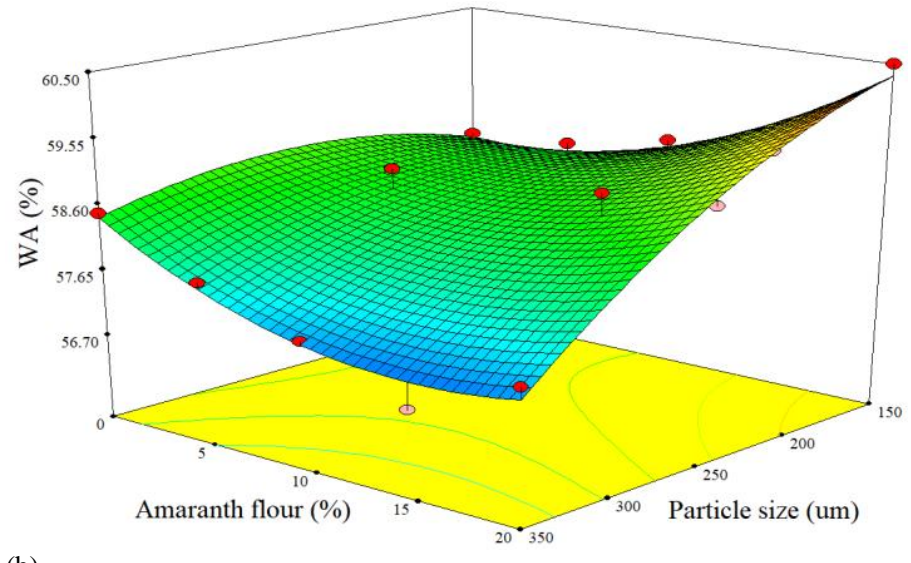

(b)

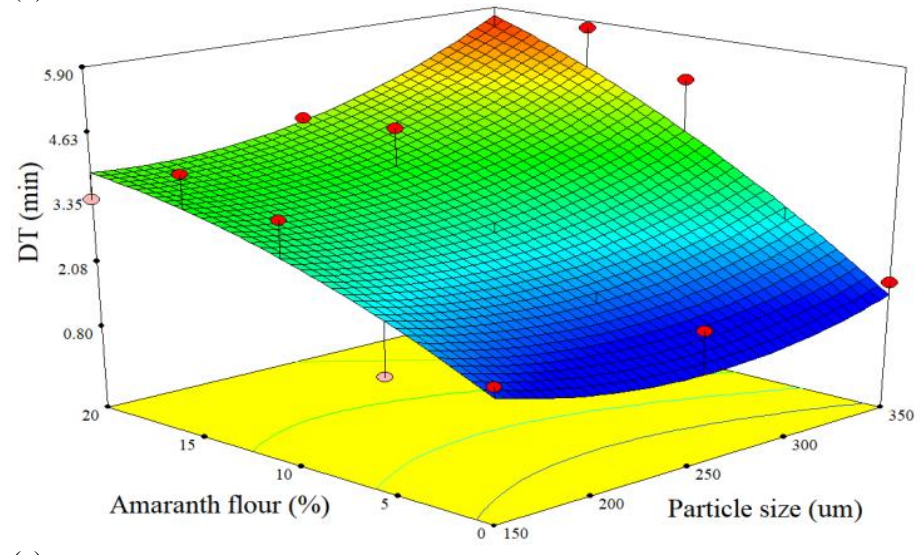

(c)

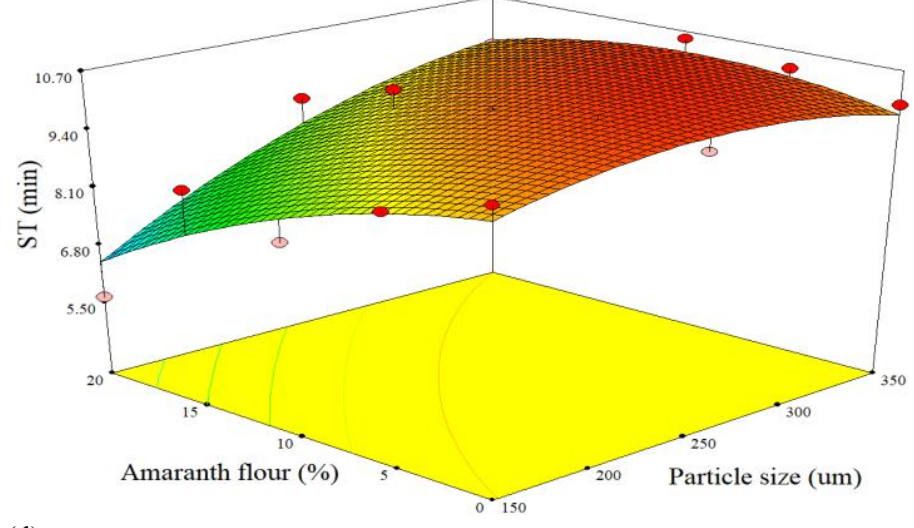

(d)

Figure 1 Response surface plot showing the combined effects of amaranth flour particle size and levels added in refined wheat flour on: Falling number index (a) and Mixolab parameters during dough development stage: (b) water absorption (WA), (c) development time (DT) and (d) stability (ST)

This behaviour was probably related to the addition of non-gluten flour which diminishes dough viscoelastic properties (Mohamed et al., 2014). The weakening of the gluten network can be probably attributed to an intense incompatibility between the protein spectrum of amaranth and the wheat gluten protein. A similar observation on the incompatibility between the protein spectrum of pulses and the semolina gluten protein was reported by Mohamed $\boldsymbol{e t}$ al. (2014).

\section{Effects of formulation samples on protein weakening stage}

Due to the mechanical shear and temperature constraint, protein weakening occurs and $\mathrm{C} 2$ torque decreased to the minimum value. The value of $\mathrm{C} 2$ torque was significantly influenced $(p<0.0001)$ by the particle size and level of AF addition in WF (Table 2). Through ANOVA, the quadratic model was found to fit adequately the experimental data for $\mathrm{C} 2$, having a high coefficient of determination $\left(R^{2}=0.91\right)$. The particle size and AF addition level and the interaction term between these factors have significant effect on $\mathrm{C} 2$. The results showed an increase of $\mathrm{C} 2$ as the particle size and the interaction between particle size and $\mathrm{AF}$ addition increased (Table 2). A negative effect on $\mathrm{C} 2$ torque was given by the linear regression coefficient, suggesting that the increased level of $\mathrm{AF}$ added in WF induced a $\mathrm{C} 2$ torque decrease (Figure 2a).The decrease of $\mathrm{C} 2$ 
with the AF level increase can be related to lower water availability in the dough system due the fact that the water absorption capacity of dough decrease when particle size and AF addition level increase. $\mathrm{C} 2$ torque reduction with particle size decrease, especially in the case of small particle size, may be linked either to a release of water molecules in dough or to the presence of secondary activities.

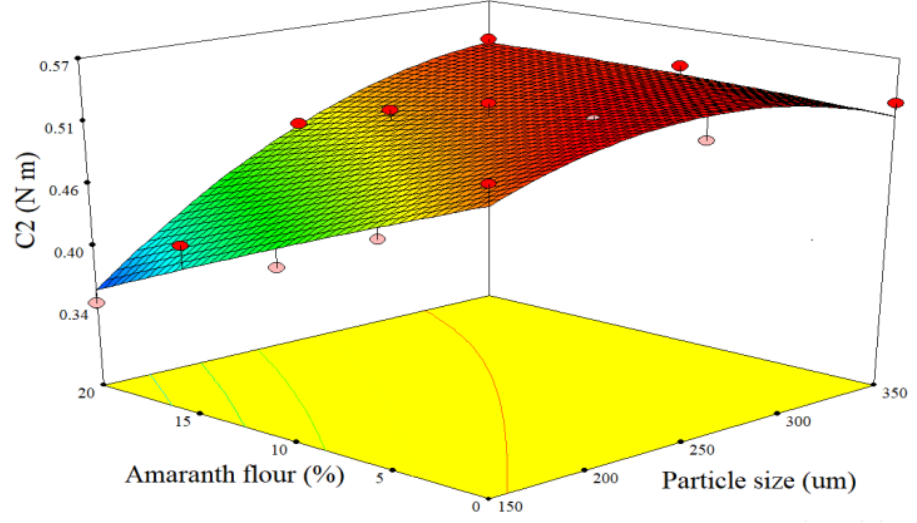

(a)

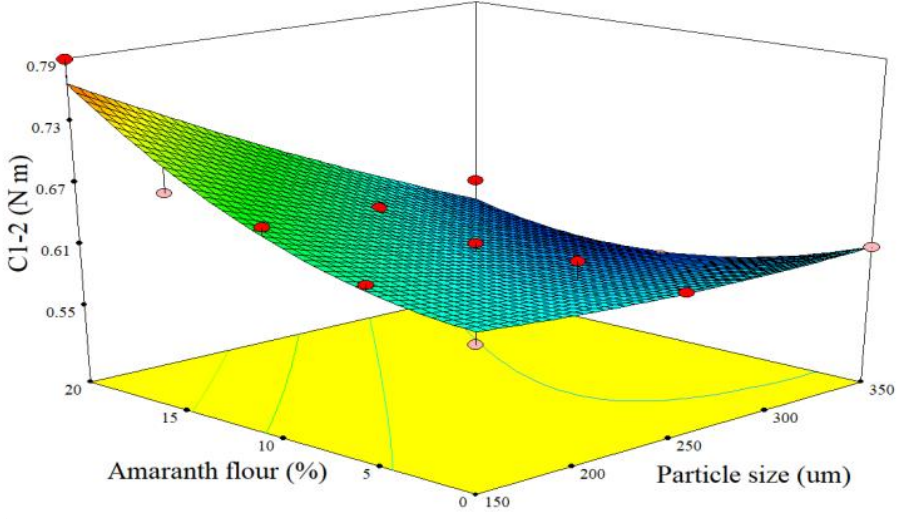

(b)

Figure 2 Response surface plot showing the combined effects of amaranth flour particle size and level added in refined wheat flour on Mixolab parameters during protein weakening stage: (a) $\mathrm{C} 2$ torque $(\mathrm{C} 2)$ and (b) difference between torques $\mathrm{C} 1$ and $\mathrm{C} 2(\mathrm{C} 1-2)$

The difference between the points $\mathrm{C} 1$ and $\mathrm{C} 2$ torque $(\mathrm{C} 1-2)$ which depicts the protein network strength under increasing heating is significantly influenced by the particle size, AF addition level and the interaction between them, as revealed by the ANOVA (Table 2). Value of $\mathrm{C} 1-2$, shows a high coefficient of determination $\left(R^{2}=0.93\right)$ and was obtained for the quadratic model, statistically significant at $\mathrm{p}<0.0001$, revealing that this model is fitting well for this data Major negative effects on C1-2 were given by particle size and by the interaction between particle size and AF addition level. The results showed an increase of C1-2 as the AF value increased, indicating a decrease of protein weakening speed under the effect of temperature increase. With particle size increase, C1-2 decreases. This fact can be due to the changes in protein network structure; proteins become less compact, favouring the enzymatic attacking points and leading to a rise in the speed of protein weakening due to the heat. This result can be also related to the area specific surface of amaranth starch that is larger than for wheat starches and it makes them more sensitive to hydrolysis by $\alpha$-amylase than wheat starch (Tester et al., 2004). The effect of particle size and AF addition level in wheat flour on protein network strength under increasing heating is shown in Figure 2b, revealing that under combined effect between particle size and $\mathrm{AF}$ addition level, the protein network becomes weaker due to heat.

\section{Effects of formulation samples on starch gelatinization stage}

As heating proceeds, the starch changes occurred being highlighted by starch gelatinization, $\mathrm{C} 3$ torque and difference between $\mathrm{C} 3$ and $\mathrm{C} 2$ torques (C3-2). The particle size, AF addition level and the interaction between these ones significantly $(p<0.05)$ affect peak torque (C3) which is associated with the starch gelatinization process that occur when dough is heated above $60{ }^{\circ} \mathrm{C}$. Low amylose content in the amaranth starch (Corke et al., 2015) is the main reason for a significantly lower C3 torque in amaranth-wheat composite flour compared to the control. Similar observations regarding starch gelatinization process were reported by Ahmed et al. (2019) for quinoa flour. The linear coefficient of the $\mathrm{AF}$ addition level indicates a significant negative influence on the torque $\mathrm{C} 3$, while particle size has a positive effect. Through ANOVA, the quadratic model was found to fit adequately the experimental result for $\mathrm{C} 3$ torque (Table 2). According to Figure 3a, C3 gradually decreased with the amaranth substitution increase and higher level of AF (20\%) addition in wheat flour lead to a dropped value for $\mathrm{C} 3$ torque $(1.32 \mathrm{~N} \cdot \mathrm{m})$ which was obtained for small particle size. This can be due to the amylase activity of amaranth flour and the amylose-lipid complexes formed during heating of starch slurries. These results are in agreement with those found by Lorenz (1981), who reported a gradually decreased of maximum viscosity with amaranth level added in wheat flour increase from 3 to $15 \%$. The decrease of particle size leads to a decrease of $\mathrm{C} 3$ torque, the small particles fraction considered as starch-enriched particle cause a lower C3 torque compared to coarse particles that can be considered as fiberenriched particle fractions. Due to the large surface, the small particle sizes compete for water with starch granules from wheat flour, resulting in a decrease of dough viscosity. Similar observation was made by Ahmed et al. (2019) and Singh et al. (2019) for quinoa and corn flour and they reasoned that the larger particles have smaller surface area with lower swelling, which contributed to higher pasting viscosities. The difference among particle fractions could be related to the microstructure of the amaranth-starch that governs the water absorption and swelling, being also influenced by the composition of the particles. The gelatinization of starch measured by the torque $\mathrm{C} 3$ reflect breaking of hydrogen bonds in the crystalline regions and assimilation of water by hydrogen bonds and water absorption by non-starch polysaccharides and protein (Yu et al., 2012).

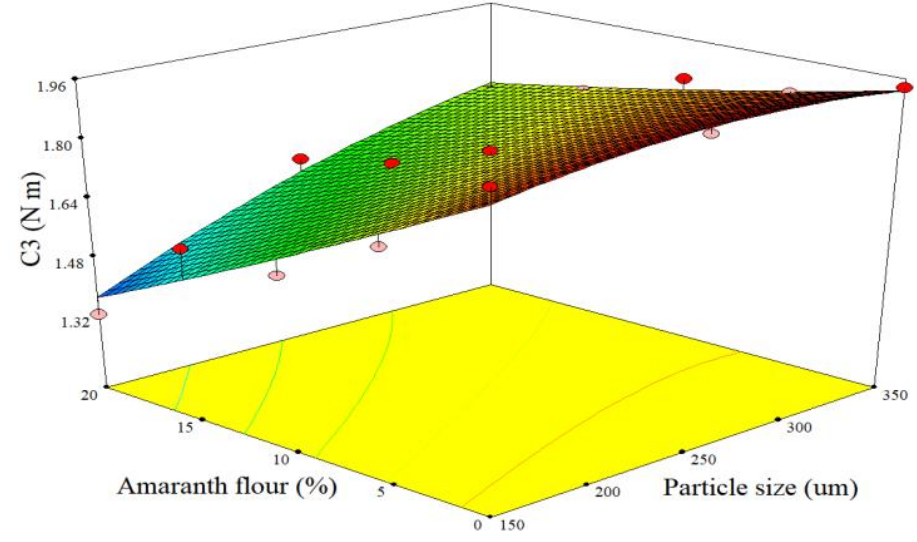

(a)

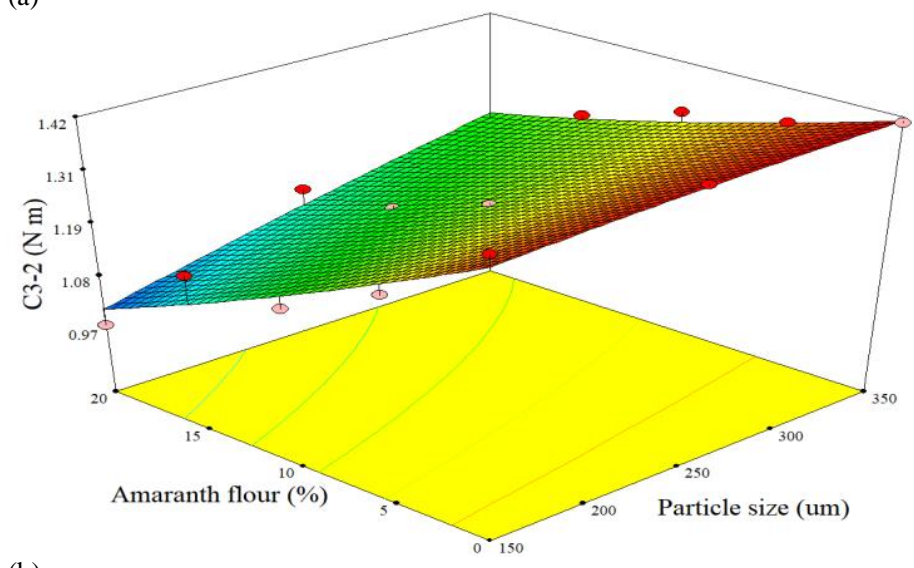

Figure 3 Response surface plot showing the combined effects of amaranth flour particle size and level added in refined wheat flour on Mixolab parameters during starch gelatinization stage: (a) C3 torque (C3) and (b) difference between torques $\mathrm{C} 3$ and $\mathrm{C} 2(\mathrm{C} 3-2)$

The effects of particle size and AF addition level in wheat flour on the difference between $\mathrm{C} 3$ and $\mathrm{C} 2$ torques (C3-2) expressed as their corresponding regression coefficients in the quadratic regression model are shown in Table 2 . The linea term of particle size indicates a significant positive influence on C3-2, while the linear term of the AF addition level has a significant negative effect. C3-2 was significantly correlated $(p<0.05)$ with the interaction effect of particle size and $\mathrm{AF}$ addition level in wheat flour. The quadratic regression model represent adequately the experimental data of $\mathrm{C} 3-2$, the $R^{2}$ value $(0.95)$, confirming the adequacy of the model. The effect of particle size and AF addition level in wheat flour can be seen in Figure 3b, indicating an increase of C3-2 with particle size increase. This can be probably due to the combined effect of the $\alpha$-amylase activity increase in composite flour and to the compounds that exist in particle fractions composition of amaranth flour. The hydrolysis process of starch, intensified by a high $\alpha$-amylase activity, will lead to a decrease in viscosity (de Souza and Magalhães, 2010) and increase the free water amount from the dough; however the hydrocolloid molecules from the amaranth flour will reducethe availability of water for granule swelling (Mironeasa and Codină 2017; Pahwa, 2016). 


\section{Effects of formulation samples on the stability of hot-formed starch gel}

The effects of formulation factors, particle size and AF added amount in whea flour on the $\mathrm{C} 4$ torque corresponding to hot starch stability gel (cooking stability) showed a significant $(\mathrm{p}<0.05)$ decrease with the AF addition level increase, while particle size had a non-significant effect $(\mathrm{p}>0.05)$ (Table 2). Data obtained for the quadratic regression model indicates adequately results of $\mathrm{C} 4$, indicating a high $R^{2}$ value of 0.95 . As can be seen in Figure 4a, as level the of AF increased and particle size decreased, while $\mathrm{C} 4$ torque and the stability of the gel formed decreased. Paste heating at high temperature results in viscosity drop attributed to the paste resistance to disintegrate at high temperature. The lowest $\mathrm{C} 4$ torque value $(1.09 \mathrm{~N} \cdot \mathrm{m})$ was obtained for small particle size at higher level of AF $(20 \%)$ used in wheat flour, whereas the highest value $(1.783 \mathrm{~N} \cdot \mathrm{m})$ was obtained for large particle size at lower level of $\mathrm{AF}(5 \%)$. The decrease of $\mathrm{C} 4$ can be due to the particle fraction composition and probably to the compounds present in small particle size content, like soluble fiber which can bind water by the hydrogen bonds, causing a decrease of available water for the starch granules. Pectic polysaccharides and xyloglucans in varying amounts, depending on the fiber fraction, were found mainly in the amaranth fiber (Wefers et al., 2015). The low amylose content of small particle size can lead to a more fluid gel formation without such a defined three-dimensional structure (Tang and Copeland, 2007), contributing to a decrease in the $\mathrm{C} 4$ value.

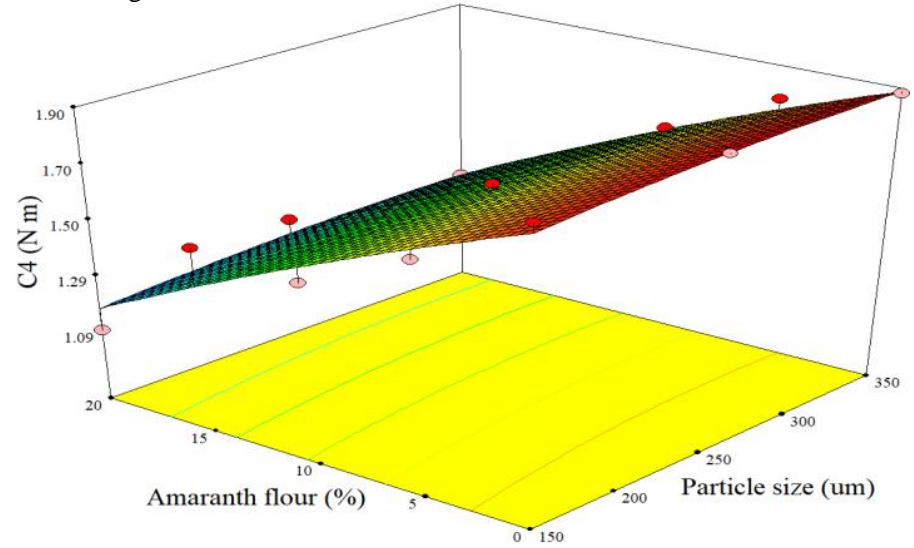

(a)

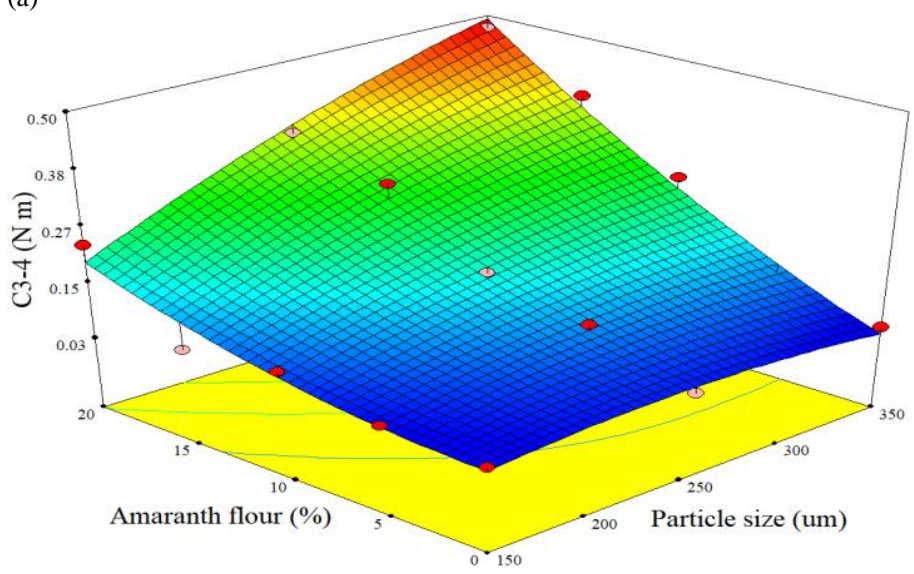

(b)

Figure 4 Response surface plot showing the combined effects of amaranth flour particle size and level added in refined wheat flour on Mixolab parameters during cooking stage: (a) $\mathrm{C} 4$ torque (C4) and (b) difference between torques $\mathrm{C} 3$ and $\mathrm{C} 4$ (C3-4)

The quadratic regression model was fitted for the difference between points $\mathrm{C} 3$ and $\mathrm{C} 4$ torques peak values (C3-4), indicating that the model explains $96 \%$ of the observed results fluctuation. C3-4 was significantly associated with the formulation factors, particle size and AF addition level in WF and with the interaction between them (Table 2). The effect of formulation factors on C3-4 is showed in Figure 4b, indicating the ability of the particle size and AF level and of their interaction to increase the C3-4. Since the amaranth flour did not bring amylase in dough system, as it can be seen from the $\mathrm{FN}$ index values variation, these parameter values increase as compared to the sample where no amaranth flour is added. All the C3-4 presented high values in the samples with amaranth flour addition, depending on the particle size. On the other hand, C3-4 increase can suggest reduced gel stability when hot and this may be related to the starch damage process

\section{Effects of formulation samples on starch retrogradation}

The starch retrogradation during the cooling period of the Mixolab is represented by the C5 torque and the difference between $\mathrm{C} 5$ and $\mathrm{C} 4$ peaks (C5-4), determinated by starch proportions of amylose and amylopectin (BeMiller, 2019), since amylose recrystallizes faster than amylopectin. Quadratic model was fitted for C5 torque and ANOVA results shows that it is well adjusted to the experimental data obtained, being highly significant $\left(R^{2}=0.93\right)$. The significant effect $(p<0.05)$ of AF level added in wheat flour was observed on C5 torque, indicating low retrogradation and recrystalization, whereas the particle size has a non-significant effect $(p>0.05)$. The low starch retrogradation in amaranthwheat composite flour may be due to the different nature of the starch, and to the small granules of amaranth which present a low tendency toward retrogradation. In addition, the higher levels of phenolics can contribute to retrogradation lowering (Wu et al., 2009). The structure reorganization of starch may be beneficial for prolonging the hardening of bakery products during storage (Cai $\boldsymbol{e}$ al., 2014). Response surface plot for $C 5$ torque showed that an increased level of $\mathrm{AF}$ added in WF decreased C5 torque (Figure 5a).

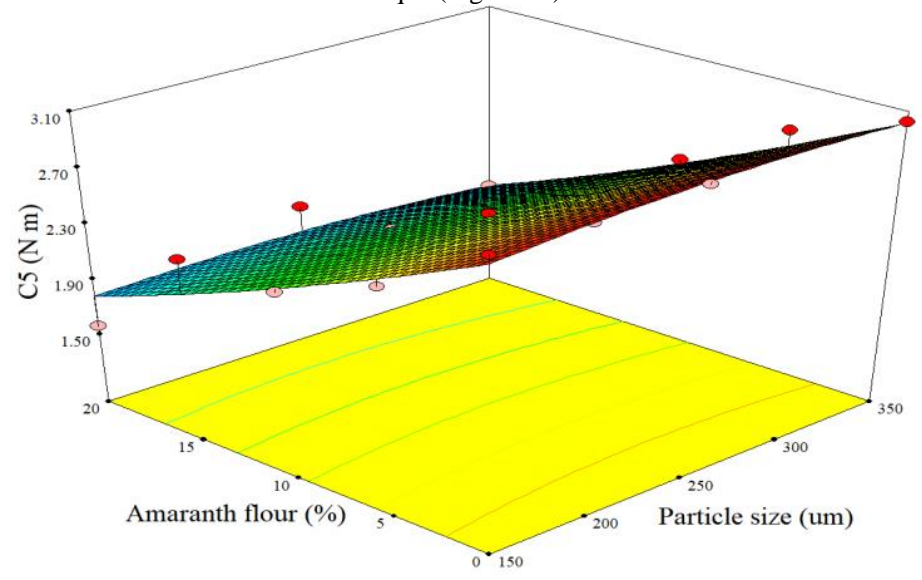

(a)

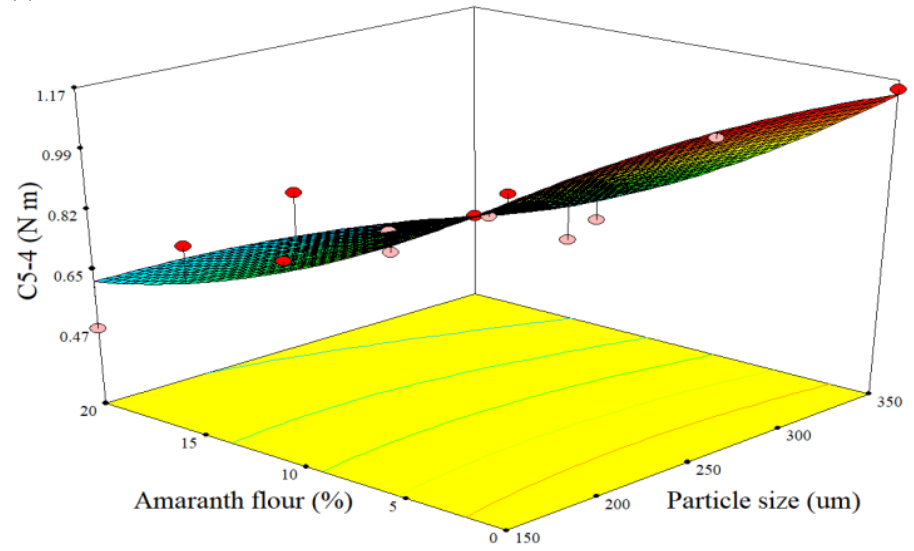

(b)

Figure 5 Response surface plot showing the combined effects of amaranth flour particle size and level added in refined wheat flour on Mixolab parameters during starch retrogradation: (a) C5 torque (C5) and (b) difference between torques C5 and $\mathrm{C} 4(\mathrm{C} 5-4)$

The quadratic regression model obtained for the difference between $\mathrm{C} 5$ and $\mathrm{C} 4$ torques $(\mathrm{C} 5-4)$ showed a good correlation coefficient $\left(R^{2}=0.95\right)$. It can be seen from Table 2 that C5-4 was significantly $(\mathrm{p}<0.05)$ influenced by the ASF level added in wheat flour, particle size showing a non-significant effect $(p>0.05)$ on C5-4. The effect of PS and ASF level addition in wheat flour on C5-4 is shown in Figure $5 \mathrm{~b}$. The response surface plot revealing reveals that the lowest value for C5-4 $(0.471 \mathrm{~N} \cdot \mathrm{m})$ is obtained at maximum ASF level $(20 \%)$ of small particle size added in wheat flour. It seems that amaranth flour addition limits starch retrogradation preserving bread freshness. This observation is in agreement with the finding reported by Collar and Angioloni (2014) which shows that amaranth flour has a positive impact on bread keeping behaviour during aging, revealing long term storage.

\section{Optimization}

The optimization highlighted that the most suitable composite flour would be with $9.74 \%$ amaranth flour of $280 \mu \mathrm{m}$ particle size, with predicted responses shown in Table 3 . There are no significant differences between the results of the water absorption, dough stability and protein weakening (C2 and $\mathrm{C} 1-2)$ of optimized and control sample. Therefore, optimal dough formulation can retain 
gas, especially during the early stage of bread similar to the control sample. An increase of dough development time can suggest an increase of gluten network strength which revealed that the optimal dough can sustain for a longer the mechanical treatment during the bread making process compared to the control The slight decrease of specific parameters in heating stage indicate that the optimal formulation can be suitable for bread-making, whereas the parameters in the cooling stage explain that products of amaranth flour dough do not present problems of staling and can be maintained for longer time.

Table 3 Wheat flour dough control sample and optimized amaranth-wheat flour sample

\begin{tabular}{lcc}
\hline \multirow{2}{*}{ Parameters } & \multicolumn{2}{c}{ Values } \\
\cline { 2 - 3 } & Optimized sample & Control sample \\
\hline FN $(\mathrm{s})$ & 316.37 & 313.13 \\
CH $(\mathrm{g} / 100 \mathrm{~g})$ & 58.45 & 58.43 \\
DT $(\mathrm{min})$ & 2.85 & 1.43 \\
ST $(\mathrm{min})$ & 9.97 & 9.78 \\
C2 $(\mathrm{N} \cdot \mathrm{m})$ & 0.52 & 0.51 \\
C1-2 $(\mathrm{N} \cdot \mathrm{m})$ & 0.60 & 0.60 \\
C3 $(\mathrm{N} \cdot \mathrm{m})$ & 1.77 & 1.92 \\
C3-2 $(\mathrm{N} \cdot \mathrm{m})$ & 1.25 & 1.41 \\
C4 $(\mathrm{N} \cdot \mathrm{m})$ & 1.59 & 1.89 \\
C3-4 $(\mathrm{N} \cdot \mathrm{m})$ & 0.18 & 0.03 \\
C5 $(\mathrm{N} \cdot \mathrm{m})$ & 2.40 & 3.02 \\
C5-4 $(\mathrm{N} \cdot \mathrm{m})$ & 0.81 & 1.13 \\
\hline
\end{tabular}

The improvement of refined wheat flour with amaranth lead to C3, C4 and C5 torques decrease due to the effect of wheat starch dilution and also, as a result of proteins interactions. The origin of the proteins has been suggested to be responsible for modifying pasting and gelling properties of cereal starches (Marco and Rosell, 2008), due to the thermal induced gelation process of the proteins after the aggregation of the polymer chains that cause huge modifications in the rheological behaviour of the proteins. However, the starch retrogradation indicates that bread freshness can be maintained for longer time compared to the control bread.

\section{CONCLUSIONS}

A multi-response optimization study helped us to find the optimal particle size and amaranth level added in refined wheat flour in order to achieved a dough with the best rheological characteristics. The effect of particle size and amaranth level added on the response variables could be accurately predicted by the quadratic type models. By applying numerical technique and desirability function, the optimum particle size and level of amaranth flour addition was obtained. The best formulation giving the desirable rheological characteristics comprises of $9.74 \%$ amaranth flour of $280 \mu \mathrm{m}$ particle size.

Acknowledgments: The authors thank Arcada Research laboratory, Arcada Mill, Romania for technical support.

\section{REFERENCES}

AHMED, J., THOMAS, L., \& ARFAT, Y.A. (2019). Functional, rheological, microstructural and antioxidant properties of quinoa flour in dispersions as influenced by particle size. Food Research International, 116, 302-311. https://doi.org/10.1016/j.foodres.2018.08.039

AHMED, J., AL-ATTAR, H., \&ARFAT, Y.A. (2016). Effect of particle size on compositional, functional, pasting and rheological properties of commercial water chestnut flour. Food Hydrocolloids, 52, 888-895. https://doi.org/10.1016/j.foodhyd.2015.08.028

AHMED, J., AL-JASSAR, S., \&THOMAS, L. (2015). A comparison in rheological, thermal, and structural properties between Indian Basmati and Egyptian Giza rice flour dispersions as influenced by particle size. Food Hydrocolloids, 48, 72-83.https://doi.org/10.1016/j.foodhyd.2015.02.012

AKIN-IDOWU, P., OYERONKE, A.E., ODUNOLA, M., YEMISI, O., \&OLAGUNJU, Y.O. (2017). Nutritional evaluation of five species of grain amaranth -An underutilized Crop. International Journal of Science, 6(1), 18-27. DOI: $10.18483 / \mathrm{ijSci} .1131$

ALVAREZ-JUBETE, L., ARENDT, E.K., \& GALLAGHER, E. (2009) Nutritive value and chemical composition of pseudocereals as gluten-free ingredients. International Journal of Food Sciences and Nutrition, 60, 240-257. https://doi.org/10.1080/09637480902950597

AMJID, M. R., SHEHZAD, A., HUSSAIN, S., SHABBIR, M. A., KHAN, M. R., \& SHOAIB, M. (2013). A comprehensive review on wheat flour dough rheology. Pakistan Journal of Food Sciences, 23(2), 105-123.

ANGIOLONI, A., \&COLLAR, C. (2009). Gel, dough and fibre enriched fresh breads: Relationships between quality features and staling kinetics. Journal of Food Engineering, 91(4), 526-532. https://doi.org/10.1016/j.jfoodeng.2008.09.033
BHATTACHARYA, S., NARASIMHA, H.V., \&BHATTACHARYA, S. (2006) Rheology of corn dough with gum arabic: Stress relaxation and two-cycle compression testing and their relationship with sensory attributes. Journal of Food Engineering, 74(1), 89-95.

BeMILLER, J.N. (2019). Starches: Molecular and granular structures and properties: Chemistry for Food Scientists, 3 rd ed. 159-189. Elsevier.

BRESSIANI, J., ORO, T., DA SILVA, P., MONTENEGRO, F., BERTOLIN, T., GUTKOSKI, L., \& GULARTE, M. (2019). Influence of milling whole wheat grains and particle size on thermo-mechanical properties of flour using Mixolab Czech Journal of Food Sciences, 37(4), 276-284. https://doi.org/10.17221/239/2018-CJFS

CAPRILES, V.D., ALMEIDA, E.L., FERREIRA, R.E., AREAAS, J.A.G., STEEL C.J., \&CHANG, Y.K. (2008). Physical and sensory properties of regular and reduced-fat pound cakes with added amaranth flour. Cereal Chemistry,85, 614 8. https://doi.org/10.1094/CCHEM-85-5-0614

CÁRDENAS-HERNÁNDEZ, A., BETA, T., LOARCA-PIÑA, G., CASTAÑOTOSTADO, E., NIETO-BARRERA, J. O., \&MENDOZA, S. (2016). Improved functional properties of pasta: Enrichment with amaranth seed flour and dried amaranth leaves. Journal of Cereal Science, 72, 84-90. https://doi.org/10.1016/j.jcs.2016.09.014

CASELATO-SOUSA, V.M., \& AMAYA-FARFÁN, J. (2012). State of knowledge on amaranth grain: a comprehensive review. Journal of Food Science, 77(4): 93-104. DOI: 10.1111/j.1750-3841.2012.02645.x

CHAUHAN, A., SAXENA, D. C., \& SINGH, S. (2015). Total dietary fibre and antioxidant activity of gluten free cookies made from raw and germinated amaranth (Amaranthus spp.) flour. LWT-Food Science and Technology 63, 939945. https://doi.org/10.1016/i.lwt.2015.03.115

COLLAR, C., \&ANGIOLONI, A. (2014). Pseudocereals and teff in complex breadmaking matrices: impact on lipid dynamics. Journal of Cereal Science 59(2), 145-154. https://doi.org/10.1016/j.jcs.2013.12.008

CORKE, H., CAI, Y.Z., WU, H.X. (2016). Amaranth: overview In: Wrigley C, Corke H, Seetharaman K, Faubion J, editors. Encyclopedia of food grains. Oxford: Academic Press. p 287-96.

CAI, L., CHOI, I., HYUN, J.N., JEONG, Y.K., \&BAIK, B.K. (2014). Influence of bran particle size on bread-baking quality of whole grain wheat flour and starch retrogradation. Cereal Chemistry, 91, 6571. https://doi.org/10.1094/CCHEM-02-13-0026-R

CODINA, G.G., \& MIRONEASA, S. (2013). Influence of mixing speed on dough microstructure and rheology. Food Technology and Biotechnology, 51(4) 509-519. https://hrcak.srce.hr/114467

DE LA ROSA, A.B., FOMSGAARD, I.S., LAURSEN, B., MORTENSEN, A.G., OLVERA-MARTÍNEZ, L., SILVA-SÁNCHEZ, C., \& DE LEÓNRODRÍGUEZ, A. (2009). Amaranth (Amaranthus hypochondriacus) as an alternative crop for sustainable food production: Phenolic acids and flavonoids with potential impact on its nutraceutical quality. Journal of Cereal Science, 49(1), 117-121. https://doi.org/10.1016/j.jcs.2008.07.012

DE SOUZA, P.M., \& DE OLIVEIRA e MAGALHÃES, P. (2010). Application of microbial $\alpha$-amylase in industry - A review. Brazilian Journal of Microbiology, $\quad 41(4), \quad$ 850-861.https://doi.org/10.1590/S1517 83822010000400004

DHELlOT, J.R., MATOUBA, E., MALOUMBI, M.G., NZIKOU, J.M., NGOMA, D.G.S., LINDER, M., DESOBRY, S., \& PARMENTIER, M. (2006) Extraction, chemical composition and nutrional characterization of vegetable oils: Case of Amaranthus hybridus (var 1 and 2) of Congo Brazzaville. African Journal of Biotechnology, 5(11), 1095-1101.

DRAKOS, A., KYRIAKAKIS, G., EVAGELIOU, V., PROTONOTARIOU, S. MANDALA, I., \& RITZOULIS, C. (2017). Influence of jet milling and particle size on the composition, physicochemical and mechanical properties of barley and rye flours. Food Chemistry, 215, 326-332.

https://doi.org/10.1016/j.foodchem.2016.07.169

INGLETT, G.E., CHEN, D., \& LIU, S.X. (2015). Physical properties of glutenfree sugar cookies made from amaranth-oat composites. LWT-Food Science and Technology, 63, 214-220. https://doi.org/10.1016/j.lwt.2015.03.056 ICC 2010. Standard Methods of the International Association for Cereal Chemistry, 110/1, 105/2, 136, 104/1, 106/1, 107/1

IUGA, M., \&MIRONEASA, S. (2019). Grape seeds effect on refined wheat flour dough rheology: optimal amount and particle size. Ukrainian Food Journal, 799. 10.24263/2304-974X-2019-8-4-11

IUGA, M., MIRONEASA, C., \& MIRONEASA, S. (2019). Oscillatory rheology and creep-recovery behaviour of grape seed-wheat flour dough: effect of grape seed particle size, variety and addition level. Bulletin of University of Agricultural Sciences and Veterinary Medicine Cluj-Napoca. Food Science and Technology, 76(1), 40-51. http://dx.doi.org/10.15835/buasvmcn-fst:2018.0020 KALINOVA, J., \& DADAKOVA E. (2009). Rutin and total quercetin content in amaranth (Amaranthus spp.). Plant Foods Human Nutrition, 64, 68-74. doi: 10.1007/s11130-008-0104-X.

KAUR, S., SINGH, N., \&RANA, J. C. (2010). Amaranthushypochondriacus and Amaranthuscaudatus germplasm: Characteristics of plants, grain and flours. Food Chemistry, 123(4), 1227-1234. https://doi.org/10.1016/j.foodchem.2010.05.091 
KRAUJALIS, P., \& VENSKUTONIS, P.R. (2013). Optimisation of supercritical carbon dioxide extraction of amaranth seeds by response surface methodology and characterization of extracts isolated from different plant cultivars. The Journal of Supercritical Fluids, 73, 80-86. https://doi.org/10.1016/j.supflu.2012.11.009

LIU, T., HOU, G.G., LEE, B., MARQUART, L., \& DUBAT, A. (2016). Effects of particle size on the quality attributes of reconstituted whole wheat flour and tortillas made from it. Journal Cereal Science, 71, 145-152.

https://doi.org/10.1016/j.jcs.2016.08.013

Lorenz, K. (1981). Amaranthushypochondriacus - Characteristics of the starch and baking potential of the flour. Starch-Stärke, 33(5), 149-153. https://doi.org/10.1002/star.19810330502

MARCIN, K., JAROSŁAW, W., MONIKA, P., \& AGNIESZKA, W. (2016). Application of the response surface methodology in optimizing oat fiber particle size and flour replacement in wheat bread rolls. CyTA-Journal of Food, 14(1), 18-26. https://doi.org/10.1080/19476337.2015.1036309

MARTINEZ M.M., DIAZ A., \& GOMEZ M. (2014). Effect of different microstructural features of soluble and insoluble fibres on gluten-free dough rheology and bread-making.Journal of Food Engineering, 142, 49-56. https://doi.org/10.1016/i.jfoodeng.2014.06.020

MIRONEASA, S., \& CODINǍ, G.G. (2017). The mixolab rheological properties and dough microstructure of defatted mustard seed-wheat composite flours. Journal of Food Processing and Preservation, 41(5), e13130. https://ifst.onlinelibrary.wiley.com/doi/abs/10.1111/jfpp.13130

MIRONEASA, S., ZAHARIA, D., CODINĂ, G.G., ROPCIUC, S., \& IUGA, M. (2018). Effects of grape peels addition on mixing, pasting and fermentation characteristics of dough from 480 wheat flour type. Bulletin of University of Agricultural Sciences and Veterinary Medicine Cluj-Napoca. Food Science and Technology, 75(1), 27-35.http://dx.doi.org/10.15835/buasvmen-fst:0021

MIRONEASA, S., IUGA, M., ZAHARIA, D., \& MIRONEASA, C. 2019. Rheological analysis of wheat flour dough as influenced by grape peels of different particle sizes and addition levels. Food and Bioprocess Technology, 12(2), 228-245. https://doi.org/10.1007/s11947-018-2202-6

MIRONEASA, S., IUGA, M., ZAHARIA, D., \& MIRONEASA, C. (2019a) Optimization of grape peels particle size and flour substitution in white whea flour dough. Scientific Study \& Research. Chemistry \& Chemical Engineering, Biotechnology, Food Industry, 20(1), 29-42.

MIRONEASA, S., \& MIRONEASA, C. (2019). Dough bread from refined wheat flour partially replaced by grape peels: Optimizing the rheological properties. Journal of Food Process Engineering, 42(4), e13207. https://doi.org/10.1111/jfpe.13207

MOHAMMED I., AHMED A.R., \& SENGE B. (2014). Effects of chickpea flour on wheat pasting properties and bread making quality. Journal of Food Science and Technology, 51(9), 1902-1910. https://doi.org/10.1007/s13197-012-0733-9 MOREIRA, R., CHENLO, F., TORRES, M. D., \& RAMA, B. (2014). Fine particle size chestnut flour doughs rheology: Influence of additives. Journal of Food Engineering, 120, 94-99. https://doi.org/10.1016/j.jfoodeng.2013.07.025

MOREIRA, R., CHENLO, F., TORRES, M.D. \& PRIETO D.M. (2012) Technological Assessment of Chestnut Flour Doughs Regarding to Doughs from Other Commercial Flours and Formulations. Food and Bioprocess Technology, 5,2301-2310. https://doi.org/10.1007/s11947-011-0524-8

OSZVALD, M., TAMÁS, C., RAKSZEGI, M., TÖMÖSKÖZI, S., BÉKÉS, F., \&

TAMÁS, L. (2009). Effects of incorporated amaranth albumins on the functional properties of wheat dough. Journal of the Science of Food and Agriculture, 89(5), 882-889. https://doi.org/10.1002/jsfa.3528

PAHWA, A., KAUR, A., \& PURI, R. (2016). Influence of hydrocolloids on the quality of major flat breads: A review. Journal of Food Processing.https://doi.org/10.1155/2016/8750258

PALOMBINI, S.V., SWAMI, T.C., MARUYAMA, A., GOHARA, A.K. SOUZA, A.H, SOUZA, N.E., VISENTAINER, J.V., GOMES, S. T., \& MATSUSHITA, M. (2013). Evaluation of nutritional compounds in new amaranth and quinoa cultivars. Food Science and Technology, 33(2), 339-344. https://doi.org/10.1590/S0101-20612013005000051

REPO-CARRASCO-VALENCIA, R., HELLSTRÖM, J. K., PIHLAVA, J. M., \& MATTILA, P. H. (2010). Flavonoids and other phenolic compounds in Andean indigenous grains: Quinoa (Chenopodium quinoa), kañiwa (Chenopodium pallidicaule) and kiwicha (Amaranthus caudatus). Food Chemistry, 120(1), 128 133. https://doi.org/10.1016/j.foodchem.2009.09.087

ROSELL, C.M., CORTEZ, G., \& REPO-CARRASCO, R. (2009). Breadmaking use of the Andean crops quinoa (Chenopodium quinoa), kañiwa (Chenopodiumpallidicaule), kiwicha (Amaranthuscaudatus), and tarwi (Lupinusmutabilis). Cereal Chemeistry, 86(4), 386-392. https://doi.org/10.1094/CCHEM-86-4-0386

ROSELL, C. M., COLlAR, C., \& HAROS, M. (2007). Assessment of hydrocolloid effects on the thermo-mechanical properties of wheat using the Mixolab. Food Hydrocolloids, 21, 452-462. https://doi.org/10.1016/j.foodhyd.2006.05.004

SAKHARE, S. D., INAMDAR, A. A., SOUMYA, C., INDRANI, D., \& RAO, G. V. (2014). Effect of flour particle size on microstructural, rheological and physico-sensory characteristics of bread and south Indian parotta. Journal of
Food Science and Technology, 51(12), 4108-4113. https://doi.org/10.1007/s13197-013-0939-5

SANZ-PENELLA, J. M., WRONKOWSKA, M., SORAL-SMIETANA, M., \& HAROS, M. (2013). Effect of whole amaranth flour on bread properties and nutritive value. LWT-Food Science and Technology, 50(2), 679-685. https://doi.org/10.1016/j.lwt.2012.07.031

SCHOENLECHNER, R., SIEBENHANDL, S., \& BERGHOFER, E. (2008) Pseudocereals: Gluten-free cereal products and beverages $1^{\text {st }}$ ed. 7,149 190.Academic Press.

SINGH, N., GUJRAL, H.S., KATYAL, M., \& SHARMA, B. (2019). Relationship of Mixolab characteristics with protein, pasting, dynamic and empirical rheological characteristics of flours from Indian wheat varieties with diverse grain hardness. Journal of Food Science and Technology, 56, 2679-2686. https://doi.org/10.1007/s13197-019-03756-z

STRUYF, N., VERSPREET, J., \& COURTIN, C.M. (2016). The effect of amylolytic activity and substrate availability on sugar release in non-yeasted dough. Journal of Cereal Science, 69, 111-118 https://doi.org/10.1016/j.jcs.2016.02.016

SUANDARRAM, A., PANDURANGAPPA, T., \& MURTHLY, K. (2014). $\alpha$ amylase production and applications: A review. Journal of Applied \& Environmental Microbiology, 2, 166-175. DOI:10.12691/jaem-2-4-10

SUDHA, M.L., \&LEELAVATHI, K. (2012). Effect of blends of dehydrated green pea flour and amaranth seed flour on the rheological, microstructure and pasta making quality. Journal of Food Science and Technology-Mysore, 49,71320. DOI:10.1007/s13197-010-0213-Z

TANG, M. C., COPELAND, L. 2007. Analysis of complexes between lipids and wheat starch. Carbohydrate Polymers, 67(1), 80-85. https://doi.org/10.1016/j.carbpol.2006.04.016

TESTER, R. F., KARKALAS, J., \& QI, X. (2004). Starch structure and digestibility enzyme-substrate relationship. World's Poultry Science Journal, 60(2), 186-195. http://dx.doi.org/10.1079/WPS20040014

VALCÁRCEL-YAMANI, B., \& LANNES, S.D.S. (2012). Applications of quinoa (Chenopodium quinoa Willd.) and amaranth (Amaranthus spp.) and their influence in the nutritional value of cereal based foods. Food and Public Health 2(6), 265-275. DOI: 10.5923/j.fph.20120206.12

VENSKUTONIS, P.R., \& KRAUJALIS, P. (2013). Nutritional components of amaranth seeds and vegetables: a review on composition, properties, and uses. Comprehensive Reviews in Food Science and Food Safety, 12(4), 381-412. DOI: 10.1111/1541-4337.12021

VITALI, D., DRAGOJEVIĆ, I.V.,\&ŠEBEČIĆ, B. (2008). Extractable phenolic compounds and antioxidative properties of different wheat-based integral biscuits. In: D Curic, editor. Proceedings of the 2008 Joint Central European Congress. Vol. 1. p 407-12.

WANG N., HOU G.G., KWEON M., \& LEE B. (2016). Effects of particle size on the properties of whole-grain soft wheat flour and its cracker baking performance. Journal Cereal Science, 69, 187-219. https://doi.org/10.1016/j.jcs.2016.03.010

WEFERS, D., TYL, C.E., \& BUNZEL, M. (2015). Neutral pectin side chains of amaranth (Amaranthushypochondriacus) contain long, partially branched arabinans and short galactans, both with terminal arabinopyranoses. Journal of Agricultural and Food Chemistry, 63(2), 707-715. https://doi.org/10.1021/jf505283x

WU, C.J., \& HAMADA, M.S. (2011). Experiments: planning, analysis, and optimization (Vol. 552). John Wiley \& Sons.

Yu, S., Ma, Y., Menager, L., \& Sun, D.W. (2012). Physicochemical properties of starch and flour from different rice cultivars. Food and Bioprocess Technology, 5(2), 626-637. https://doi.org/10.1007/s11947-010-0330-8 